\title{
Miningo
}

http://dx.doi.org/10.1590/0370-44672019730045

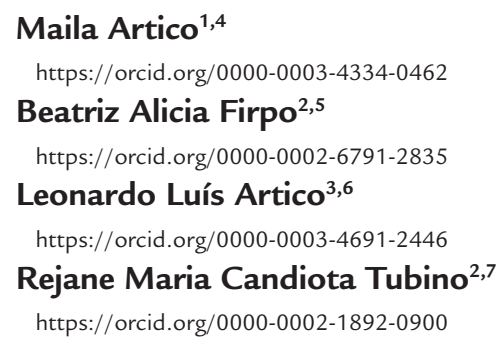

${ }^{1}$ Fundação Estadual de Proteção Ambiental Henrique Luiz Roessler - FEPAM,

Porto Alegre - Rio Grande do Sul - Brasil.

${ }^{2}$ Universidade Federal do Rio Grande do Sul - UFRGS, Laboratório de Estudos Ambientais para Metalurgia, Porto Alegre - Rio Grande do Sul - Brasil.

${ }^{3}$ Universidade Estadual de Campinas - UNICAMP, Instituto de Biologia, Campinas - São Paulo - Brasil.

E-mails: ${ }^{4}$ maylaartico@hotmail.com, bia.firpo7@gmail.com, ${ }^{6}$ leonardoartico@yahoo.com.br 7rejane.tubino@gmail.com

\section{Integrated use of sewage sludge and basalt mine waste as soil substitute for environmental restoration}

\begin{abstract}
If not managed properly, mining waste can be detrimental to the environment. In addition, sewage treatment plants produce sludge, a biowaste rich in organic matter which is often sent to landfills. The present study evaluated the use of sewage sludge as an amendment for mine waste from a basalt quarry as an alternative to the use of soil from borrow areas during environmental restoration. An ex situ experiment was developed at the Federal University of Rio Grande do Sul - UFRGS. The experimental delineation compared the addition of two sources of organic matter (sewage sludge SS and cover soil from that same region - CS) to basalt waste rock (BWR) against the sole use of cover soil, which a current restoration technique. The graminoid Avena strigosa (black oats) and soil fertility tests were used as indicators of soil conditions. Amending BWR with SS led to the best physical and chemical conditions and the highest production of dry matter in comparison to the use of CS as amendment or its single use as cover soil. These results show that mixing SS to BWR can be used as a substitute for cover soil during the environmental restoration of basalt quarries, further contributing to the final disposal of these materials.
\end{abstract}

Keywords: biosolid; mine degradation; quarry restoration; biowaste; soil amendment.

\section{Introduction}

Changes to the environment are intrinsically associated with mining activities. To be more specific, the extraction of ore leads to physical and biological impacts which then generate social and economic problems (Artico et al., 2018). The intensity of these impacts depends on factors such as: kind of ore, extraction and beneficiation techniques (Curi, 2017). In this context, it is necessary to improve environmental restoration techniques to reduce mining environmental impacts.

Most of Brazilian mineral production is performed by open-pit methods altering the landscape (Curi, 2017). The extraction of basalt, a material widely used as a construction aggregate, is characterized by a complete removal of the vegetation and overburden material (soil and rocks on top of the ore) and the production of spoils, rock waste and other possible by-products. The by-products generated during basalt mining have low fertility, which negatively affect the establishment of new vegetation cover in areas impacted by mining. Sewage sludge has been used as an alternative source of nutrients for plants whether for agricultural or environmental purposes (Tamanini et al., 2008; Waterhouse et al., 2014; Tian, 2015). More specifically, mine sites have taken advantage of organic matter input into soils and mine spoils during reclamation procedures (Wijesekara et al., 2016; Firpo, 2015, Almendro-Candel, 2014; Halofsky, 2005). In Brazil, as in other developing countries, the use of sewage sludge in soils is gaining more prominence as a consequence of the expansion of basic sanitation which has led to significant increases in sewage sludge production (Bittencourt, Serra and Aisse, 2017).

In view of the above, this research aims to contribute to studies related to 
the environmental restoration of mine sites by optimizing the use of rock waste after mixing it with the residue of other processes to turn it into a soil capable

\section{Materials and methods}

The materials used in this experiment were: basalt waste rock (BWR), cover soil (CS), sewage sludge (SS) from an Upflow Anaerobic Sludge Blanket reactor (UASB), and Avena strigosa (black oats), a graminoid. Both BWR and CS were collected in a quarry located in the municipality of Novo Hamburgo, Rio Grande do Sul (RS), Brazil. The SS was collected at a wastewater treatment plant that belongs to a Water and Sewage Service Company (COMUSA) from the same municipality. BWR, CS and the SS were dried in a constant flux laboratory oven at $60^{\circ} \mathrm{C}$ at the Mineral and Environmental Technology Laboratory (LTM) from the University of Rio Grande do Sul - UFRGS. Black oat seeds were obtained at a retail store in the municipality Porto Alegre, RS. Sampling of supporting adequate plant growth. In order to do so, the integrated use of sewage sludge and basalt waste rock as a soil substitute for the environmental res- toration of mined areas was evaluated. The graminoid, Avena strigosa (black oats), and soil fertility tests were used as indicators of soil conditions. procedures conformed to NBR 10.007 (ABNT, 2004) for all materials.

In terms of characterization, BWR and CS were individually characterized in terms of fertility, following the methods described by Tedesco et al. (1995). The SS was characterized following CONAMA 375/2006 (BRASIL, 2006), a framework resolution which defines the criteria and procedures for the agricultural use of sewage sludge and was used as a chemical and microbial standard. More precisely, the SS samples were digested according to EPA3050 method which is a very strong acid digestor that dissolves almost all elements that could become "environmentally available"; for most samples it is not a total digestion technique (US-EPA, 1996). BWR, CS and SS had their particle size distribution analyzed following Teixeira et al. (2017). The EPA3050 analyses were performed by the laboratory of soil analysis at UFRGS, and the particle size distribution analyses were carried out at LTM.

After characterization, an experiment was delineated using five randomized blocks (replicates) organized into five treatments (Table 1), with a total of 25 experimental units (EU). This delineation took the organic carbon content present in the sewage sludge (SS) into consideration: the goal was to obtain soil mixtures containing 1.8 and $3.2 \%$ organic matter (SOM). These two percentages correspond, respectively, to $50 \%$ and $100 \%$ of the organic matter content present in the cover soil (CS) which was used as a control (treatment D).

Table 1 - Treatments A, B, C, D, and E using basalt rock waste (BRW), cover soil (CS), and sewage sludge (SS).

\begin{tabular}{c|c|c}
\hline Treatments & Materials & Organic matter content (\%) \\
\hline A & BRW & 0.1 \\
\hline B & BRW + SS & 1.8 \\
\hline C & BRW + CS & 1.8 \\
\hline D & CS & 3.2 \\
\hline E & BRW + SS & 3.2 \\
\hline
\end{tabular}

PVC containers (height $-25 \mathrm{~cm}$, diameter - $10 \mathrm{~cm}$ ) with screened bottoms were used as experimental units. In August, 2017, these tubes were labeled and filled with soil mixtures (treatments) as previously described. To acclimatize, they were kept on benches for 15 days prior to sowing using a random distribution. Then, each vessel received approximately 20 seeds of Avena strigosa. Ten days after germination, all were culled to ten plants. Plants were kept through the end of their phenological cycle which

\section{Results and discussion}

The chemical analysis with respect to the basalt rock waste - BRW is shown in Table 2. Results show low organic matter content $(0.1 \% \mathrm{OM})$ and $\mathrm{K}$ content according to the Brazilian Soil Science Society SBCS (2004). This is in accordance with Bissani et al. (2008) who state that soils occurred by November 2017 (75 days of plant growth). Soil moisture was kept around $60 \%$ of field capacity by weekly weight controls.

Prior to cutting, the height of all the plants was measured. Then, the aboveground plant tissue of all vessels was cut, washed and oven dried at $60^{\circ} \mathrm{C}$ until constant weight. The underground plant tissue was separated from the soil, washed and oven dried. Above and underground dried plant material were weighed in order to obtain total dry mass. Soil samples of all experimental units were analyzed for fertility and particle size distribution according to Tedesco et al. (1995) and Teixeira et al. (2017).

The SPSS Statistics (version 18) was used to run an analysis of variance (ANOVA) of all results. Probability values inferior to $5 \%$ were considered significant. Significant average differences were compared by Tukey tests adjusted to a significance level of $5 \%$. Graphs were obtained using GraphPad Prism 5.0. originating from basalt rocks show low $\mathrm{K}$ and high P content. There was no lack of micronutrients, except for B.

As for the cover soil - CS (Table 2), some chemical characteristics favorable to the growth and development of plants were observed, which are directly associ- ated with a "medium" soil organic matter content $(3.2 \%)$, as classified by SBCS (2004). Organic matter is indispensable for the development and maintenance of plant cover (Melo, Marques and Melo, 2001). There was no lack of macro- and micro-nutrients in the CS, except for Mn. 
Table 2 - Fertility results for basalt waste rock (BWR) and cover soil (CS) compared to the SBCS (2004) standards for soils.

\begin{tabular}{|c|c|c|c|c|}
\hline Fertility parameters & BWR & SBCS (2004) & CS & SBCS (2004) \\
\hline Clay (\%) & 13.0 & Class 4 & 13.0 & Class 4 \\
\hline $\mathrm{pH} \mathrm{H} \mathrm{H}_{2} \mathrm{O}$ & 6.5 & High & 6.4 & High \\
\hline CEC $\left(\mathrm{cmolcdm}^{-3}\right)$ & 29.4 & High & 13.5 & Medium \\
\hline Base saturation (\%) & 96.0 & High & 84.0 & High \\
\hline Aluminum saturation (\%) & 0.0 & Very low & 0.0 & Very low \\
\hline $\mathrm{P}\left(\mathrm{mg} \mathrm{dm}-{ }^{3}\right)$ & $>100$ & Very high & 18.0 & Medium \\
\hline $\mathrm{K}\left(\mathrm{mg} \mathrm{dm}-^{3}\right)$ & 48.0 & Low & 88.0 & High \\
\hline SOM - soil organic matter (\%) & 0.1 & Low & 3.2 & Medium \\
\hline $\mathrm{Ca}\left(\mathrm{cmol}_{c} \mathrm{dm}^{-3}\right)$ & 19.8 & High & 8.6 & High \\
\hline $\mathrm{Mg}\left(\mathrm{cmol}_{c} \mathrm{dm}{ }^{-3}\right)$ & 8.2 & High & 2.5 & High \\
\hline $\mathrm{S}\left(\mathrm{mg} \mathrm{dm}-{ }^{3}\right)$ & 13.0 & High & 26.0 & High \\
\hline $\mathrm{Zn}\left(\mathrm{mg} \mathrm{dm}-^{3}\right)$ & 1.9 & High & 7.2 & High \\
\hline $\mathrm{Cu}\left(\mathrm{mg} \mathrm{dm}^{-3}\right)$ & 15.0 & High & 2.7 & High \\
\hline $\mathrm{B}\left(\mathrm{mg} \mathrm{dm}-^{3}\right)$ & 0.1 & Low & 0.2 & Medium \\
\hline $\operatorname{Mn}(m g d m-3)$ & 18.0 & High & 2.0 & Low \\
\hline
\end{tabular}

Methods: $\mathrm{PH}_{(\mathrm{H} 2 \mathrm{O} 1: 1)}, \mathrm{P}$ and K Mehlich 1, $\mathrm{Ca}_{\text {exchangable, }}, \mathrm{Mg}_{\text {exchangable, }}, \mathrm{Al}_{\text {exchangable, }}, \mathrm{Mn} . \mathrm{KCl} 1 \mathrm{~mol} \mathrm{~L}^{-1}, \mathrm{~S}-\mathrm{SO}_{4} \mathrm{CaHPO} 4500 \mathrm{mg} \mathrm{L}^{-1}$, $\mathrm{Zn}$ and $\mathrm{Cu} \mathrm{HCl} 0.1 \mathrm{~mol} \mathrm{~L}^{-1}$, OM umid digestion, $\mathrm{B}$ hot water.

For particle size distribution (Table 3), the BWR was classified by Teixeira et al. (2017) standards as being sandy, since it is only $3.2 \%$ clay and $85 \%$ sand $(77.5 \%$ coarse sand). The cover soil texture is sandy loam, since it is comprised of $13.6 \%$ clay and $74.5 \%$ sand $(29.1 \%$ coarse sand). Aside from a lack of nutrients, this characterization will imply severe limitations with respect to water holding capacity.
Both factors combined make the introduction of new vegetation in BWR, without the input of amendments, extremely difficult. The cover soil, however, is naturally more fertile and capable of holding water.

Table 3 - Basalt rock waste (BRW), cover soil (CS) and sewage sludge (SS) particle size distribution.

\begin{tabular}{c|c|c|c}
\hline Particle size distribution (\%) & BRW & CS & SS \\
\hline Coarse sand & 77.5 & 29.1 & 19.2 \\
\hline Fine sand & 7.4 & 45.4 & 27.7 \\
\hline Silt & 11.9 & 11.9 & 42.9 \\
\hline Clay & 3.2 & 13.6 & 10.2 \\
\hline
\end{tabular}

The chemical analysis associated with sewage sludge collected in Novo Hamburgo, is shown in Table 4. There is a low content of available metals, all below the limits established by CONAMA 375/2006 (BRASIL, 2006). Tamanini et al., (2008) describe that levels of metals in sewage sludge vary according to the source of sewage and the wastewater plant procedures, meaning that there is no "standard" sewage sludge and they all need to be analyzed in order to avoid environmental contamination. The organic matter is $15.1 \%$, which is considered to be high (SBCS, 2004), highlighting its value as a source of nutrients for soils. As for macro- and micro-nutrients, the sewage sludge is only poor in $\mathrm{K}$ because it is highly mobile and frequently lost in the effluent (Von Sperling and Gonçalves, 2001).

Table 4 - Metal content (environmentally available) in sewage sludge and the threshold limit defined by CONAMA $375 / 2006$.

\begin{tabular}{c|c|c|c|c|c}
\hline $\begin{array}{c}\text { Available metals } \\
\left(\mathrm{mg} \mathrm{kg}^{-1}\right)\end{array}$ & Sewage Sludge & CONAMA 375/2006 & $\begin{array}{c}\text { Available metals } \\
\left(\mathrm{mg} \mathrm{kg}^{-1}\right)\end{array}$ & Sewage Sludge & CONAMA 375/2006 \\
\hline $\mathrm{Cu}$ & 69 & 1500 & $\mathrm{Ar}$ & 14 & 41 \\
\hline $\mathrm{Zn}$ & 461 & 2800 & $\mathrm{Se}$ & $<4$ & 132 \\
\hline $\mathrm{Cd}$ & $<0.2$ & 39 & $\mathrm{Ba}$ & 6 & 1300 \\
\hline $\mathrm{Cr}$ & 31 & 1000 & $\mathrm{Co}$ & 0.7 & 50 \\
\hline $\mathrm{Ni}$ & 21 & 420 & $\mathrm{Mo}$ & 0.2 & 17 \\
\hline $\mathrm{Pb}$ & 21 & 300 & $\mathrm{Hg}$ & 1500 \\
\hline
\end{tabular}


In relation to particle size characterization (physical aspect), the sewage sludge was found to have an intermediate (loam) texture by EMBRAPA standards (Teixeira et al., 2017), since it has a balanced distribution of sand, silt and clay (Table 3).

The sewage sludge (SS) micro- bial results (Table 5) show that there is Salmonella sp. present, in disagreement with CONAMA 375/2006. This is not a limiting problem; this study is the first approximation for the idea of mixing quarry mine waste with sewage sludge, and the CONAMA 375/2006 resolution itself allows for further sewage sludge treatment if necessary, which would be the case in upscaled studies. In this context, physical, chemical and biological characteristics indicate that SS is a promising option for environmental restoration purposes.

Table 5 - Sewage sludge microbial analysis and maximum concentrations allowed by CONAMA 375/2006.

\begin{tabular}{c|c|c|c}
\hline Parameter & Sewage Sludge & CONAMA 375/2006 & Units \\
\hline Viable helminth eggs & $<0.25$ & $<0.25$ & egg g $^{-1}$ TS \\
\hline Enteric viruses & $<0.25$ & $<0.25$ & PFU g $^{-1} \mathrm{TS}^{-25}$ \\
\hline Thermotolerant coliform & 490 & $<103$ & $\mathrm{MPN} \mathrm{g}^{-1} \mathrm{TS}^{-}$ \\
\hline Total coliform & $>24196$ & - & $\mathrm{MPN} \mathrm{g}^{-1}$ \\
\hline Salmonella sp. & presence & absence & $10 \mathrm{~g} \mathrm{TS}^{2}$ \\
\hline
\end{tabular}

Note: TS - total solids; PFU - plaque forming unit; MPN: most probable number.

It is important to clarify that amending areas that will not have agricultural or animal husbandry uses (like a quarry) where sewage sludge does not pose risks to human health during the first years after application. Also, keeping healthy and abundant vegetation cover, avoiding the establishment of soil erosion, and managing water runoff are practices to be implemented along with microbial population monitoring to ensure environmental protection during and after mine reclamation, whenever sewage sludge is used (Tamanini et al., 2008; Tamanini, 2004).

As shown in Table 6, treatments with higher amounts of basalt waste rock (treatments A, B, and E) correspond to the ones with higher sand and lower clay content, being classified as having a coarse texture by EMBRAPA standards (Teixeira et al., 2017). Soils with coarse texture (sandy) present low water holding capacity and high percolation and infiltration rates, being more drained and aerated in comparison to fine textured soils (Fageria and Stone, 2006). However, treatments with lower BWR content (treatments C and D) show loamy texture by EMBRAPA standards. Loam soils have good particle aggregation, along with acceptable infiltration and drainage rates (Fageria and Stone, 2006).

Table 6 - Particle size distribution in all five treatments for mixtures containing basalt waste rock (BWR), sewage sludge (SS), and cover soil (CS) for 1.8 and $3.2 \%$ soil organic matter.

\begin{tabular}{c|c|c|c|c|c}
\hline $\begin{array}{c}\text { Particle size } \\
\text { distribution } \\
(\%)\end{array}$ & $\begin{array}{c}\text { A } \\
\text { BWR } \\
(0.1 \% \text { SOM })\end{array}$ & $\begin{array}{c}\text { B } \\
\text { BWR+SS } \\
(1.8 \% \text { SOM })\end{array}$ & $\begin{array}{c}\text { C } \\
\text { BWR+CS } \\
(1.8 \% \text { SOM })\end{array}$ & $\begin{array}{c}\text { D } \\
\text { CS } \\
(3.2 \% \text { SOM })\end{array}$ & $\begin{array}{c}\text { E } \\
(3.2 \% \text { SOM })\end{array}$ \\
\hline Coarse sand & 77.5 & 65 & 47 & 29 & 73 \\
\hline Fine sand & 7.5 & 18 & 30 & 45 & 11 \\
\hline Silt & 12 & 13 & 12 & 12 & 12 \\
\hline Clay & 3 & 4 & 11 & 14 & 4 \\
\hline
\end{tabular}

SOM: soil organic matter.

In relation to soil fertility, Table 7 shows chemical results for all five treatments. With regards to acidity, the treatments ended up with different $\mathrm{pH}$ values despite the fact that the same materials were used: treatment $\mathrm{A}$ has circumneutral $\mathrm{pH}$, while treatment $\mathrm{E}$ is the most acidic, followed by treatment $\mathrm{B}$. Treatments B and E correspond to those that have sewage sludge in the mixture; it is estimated that SS acidity is lowering soil $\mathrm{pH}$. As addressed by Mello et al. (1983), the organic matter present in sewage sludge provides $\mathrm{H}^{+}$protons which tends to acidify the soil. Treatment A had the least soil organic matter (SOM), whereas treatments D and E had the most, as defined by the delineation of the treatment. It is important to emphasize that treatments D and E did not reach $3.2 \%$ SOM content as planned, even though the use of SS allowed them to reach favorable concentrations for plant development. It is known that SOM content is one of the main parameters for environmental restoration (Bronick and Lal, 2005; Uzarowicz and Skiba, 2011; Zornoza et al., 2016). More specifically, soil organic matter content (SOM) from mine sites is close to zero just after topographic adjustments. Steady SOM increases, towards values similar to those of adjacent areas, is an indication of soil restoration success. SOM content of restored areas should not be above or below surrounding levels. 
Table 7 - Fertility results of all five treatments $(n=5)$ for mixtures of basalt waste rock (BWR), sewage sludge (SS), and cover soil (CS) for 1.8 and $3.2 \%$ organic matter.

\begin{tabular}{|c|c|c|c|c|c|}
\hline Parameters & $\begin{array}{c}\text { A } \\
\text { BWR } \\
(0.1 \% O M) \\
\end{array}$ & $\begin{array}{c}\mathrm{B} \\
\text { BWR+SS } \\
(1.8 \% \text { OM })\end{array}$ & $\begin{array}{c}\mathrm{C} \\
\text { BWR+CS } \\
(1.8 \% \text { OM })\end{array}$ & $\begin{array}{c}\mathrm{D} \\
\mathrm{CS} \\
(3.2 \% \mathrm{OM})\end{array}$ & $\begin{array}{c}\mathrm{E} \\
\text { BWR+SS } \\
(3.2 \% \mathrm{OM})\end{array}$ \\
\hline $\mathrm{pH}$ & 6.8 & 5.7 & 6.3 & 6.1 & 5.3 \\
\hline SMP Index & 7.1 & 6.6 & 6.7 & 6.5 & 6.3 \\
\hline $\mathrm{H}+\mathrm{Al}\left(\mathrm{cmol}_{\mathrm{c}} \mathrm{dm}^{-3}\right)$ & 1.2 & 2.3 & 2.0 & 2.4 & 3.0 \\
\hline $\mathrm{Al}\left(\mathrm{cmol}_{\mathrm{c}} \mathrm{dm}-^{3}\right)$ & 0 & 0 & 0 & 0 & 0.1 \\
\hline $\operatorname{CEC}\left(\mathrm{cmol}_{c} \mathrm{dm}^{-3}\right)$ & 29.2 & 27.9 & 20.0 & 14.3 & 29.6 \\
\hline Base saturation (\%) & 95.8 & 91.8 & 90 & 83.6 & 89.6 \\
\hline Aluminum saturation (\%) & 0.0 & 0.0 & 0.0 & 0.0 & 0.4 \\
\hline SOM - soil org. matter (\%) & 0.1 & 2.1 & 1.8 & 2.6 & 2.7 \\
\hline$P(m g d m-3)$ & $>100$ & $>100$ & 68 & 24.8 & $>100$ \\
\hline $\mathrm{K}\left(\mathrm{mg} \mathrm{dm}-^{3}\right)$ & 55 & 45 & 45 & 46 & 44 \\
\hline $\mathrm{Ca}\left(\mathrm{cmol}_{c} \mathrm{dm}^{-3}\right)$ & 19.2 & 18.4 & 12.9 & 9.0 & 19.5 \\
\hline $\mathrm{Mg}\left(\mathrm{cmol}_{\mathrm{c}} \mathrm{dm}-{ }^{3}\right)$ & 8.7 & 7.18 & 5.04 & 2.82 & 6.9 \\
\hline $\mathrm{S}\left(\mathrm{mg} \mathrm{dm}-^{3}\right)$ & 6.3 & 120.4 & 14.6 & 20.2 & 660.6 \\
\hline $\mathrm{Cu}\left(\mathrm{mg} \mathrm{dm}^{-3}\right)$ & 1.2 & 4.5 & 1.1 & 1.1 & 5.2 \\
\hline $\mathrm{Zn}\left(\mathrm{mg} \mathrm{dm}-^{3}\right)$ & 5.2 & 25.6 & 8.6 & 14 & 35.4 \\
\hline $\operatorname{Mn}\left(m g d m-{ }^{3}\right)$ & 5.4 & 30.6 & 8.6 & 3.8 & 49.2 \\
\hline $\mathrm{B}\left(\mathrm{mg} \mathrm{dm}-^{3}\right)$ & 0.1 & 0.3 & 0.1 & 0.2 & 0.4 \\
\hline
\end{tabular}

Methods: $\mathrm{PH}_{(\mathrm{H} 2 \mathrm{O} 1: 1)}, \mathrm{P}$ and K Mehlich 1, $\mathrm{CA}_{\text {exchangeable. }}, \mathrm{Mg}_{\text {exchangeable. }}, \mathrm{AL}_{\text {exchangeable }}, \mathrm{Mn} . \mathrm{KCl} 1 \mathrm{~mol} \mathrm{~L}^{-1}, \mathrm{~S}^{-\mathrm{SO}_{4}} \mathrm{CaHPO}_{4} 500 \mathrm{mg} \mathrm{L} \mathrm{L}^{-1}, \mathrm{Zn}$ and Cu $\mathrm{HCl} 0.1 \mathrm{~mol} \mathrm{~L}^{-1}$, OM humid digestion, $\mathrm{B}$ hot water.

Treatments A, B and E had significantly higher values of $\mathrm{P}$ available for plants than treatments $\mathrm{C}$ and $\mathrm{D}$, which is consistent with the lack of $\mathrm{P}$ in the natural cover soil (CS). For K, all treatments had a low content, even though there are slightly higher values in the BWR. These results contradict that which was found for the chemical characterization of the cover soil. Mixtures that received sewage sludge ( $\mathrm{B}$ and $\mathrm{E})$ had higher $\mathrm{S}$ content than treatments that did not; the same behavior was observed for most of the macro and micronutrients. An expanded discussion including a comparison of means of the

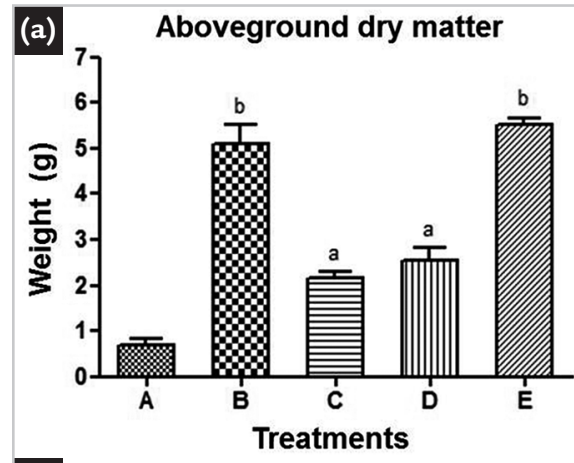

(c)

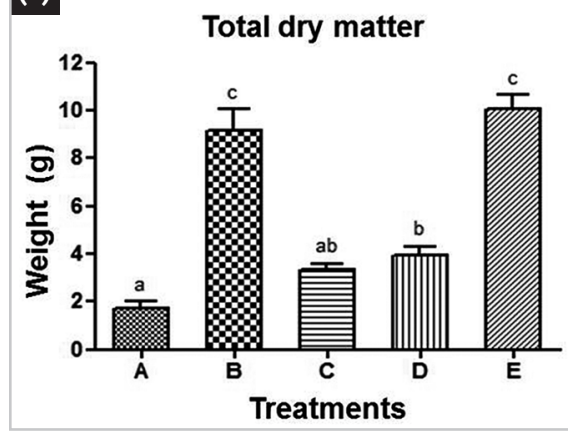

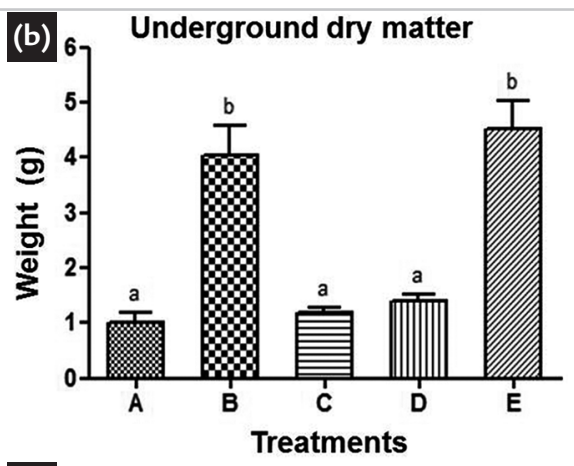

(d)

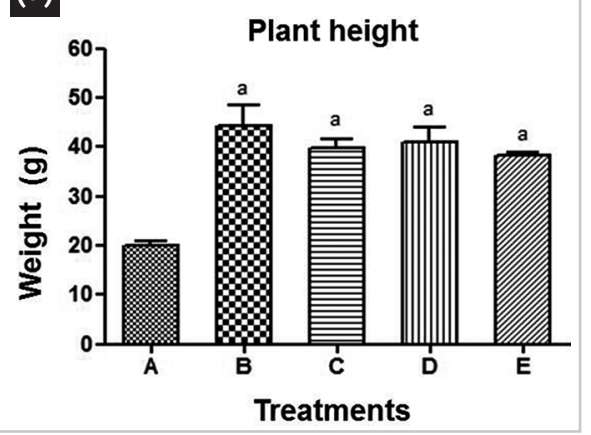

Figure 1 - Black oat dry matter production and growth.

Note: a: average aboveground dry matter; b: average underground dry matter; c: average total dry matter;

$D$ : average total height for A. strigosa. Values followed by the same letter are statistically the same following ANOVA/Tukey $(p<0.05)$ tests. 
parameters addressed in Table 7 was performed by Artico (2018).

Nutrient availability is $\mathrm{pH}$ dependent (Mello et al., 1983; Kabata-Pendias, 2001); macro-nutrientes like $\mathrm{K}$, $\mathrm{Ca}$ and $\mathrm{Mg}$ are less available in acid soils, while micro-nutrients like $\mathrm{Cu}, \mathrm{Mn}$ and $\mathrm{Zn}$ are more. Soil treatments showed results consistent with this understanding. Though $\mathrm{SS}$ is the main source of nutrients, it is also responsible for lowering the $\mathrm{pH}$, which complicates comparisons.

The growth of Avena strigosa (black oats) was measured for all five treatments proposed. Figure 1 shows average values for aboveground, underground, and total dry matter as well as average plant height. Table 8 details the total biomass produced under each treatment. Notice that treatments B and E (both with SS in the composition) do not differ significantly from one another, while having the highest dry matter content among them. Contrasting treatments B and E, treatment A had the least plant growth, given the nutrient deficiency of the basalt rock waste (BRW) (Artico, 2018). This result is not surprising and corroborates the difficulties with respect to the restoration of waste rock without the aid of amendments.

Table 8 - Average total dry matter (biomass) production $(n=5)$.

\begin{tabular}{c|c|c|c}
\hline Treatments & Targeted organic matter content (\%) & Mean values (g) & \\
\hline A BWR & 0.1 & 1.71 & $\mathrm{a}$ \\
\hline B BWR +SS & 1.8 & 9.13 & $\mathrm{c}$ \\
\hline C BWR +CS & 1.8 & 3.35 & $\mathrm{ab}$ \\
\hline D CS & 3.2 & 3.94 & $\mathrm{~b}$ \\
\hline E BWR + SS & 3.2 & 10.03 & $\mathrm{c}$ \\
\hline
\end{tabular}

Note: Values followed by the same letter do not differ statistically from one another.

In terms of dry matter production, treatments $\mathrm{B}$ and $\mathrm{E}$ (which received SS) were also statistically similar to one another. As for total height, only treatment A was statistically lower than the others. Avena strigosa dry matter production was significant- ly positively affected by treatments combining BWR and SS (treatments $\mathrm{B}$ and E) - Figure 1C. Similar results were obtained by Firpo, Amaral-Filho and Schneider (2015) and Weiler, Firpo and Schneider (2018), where the combination of coal mine waste and sewage sludge along with steel slag and rice husk ash allowed the growth of Avena strigosa (black oats) and Megathyrsus maximus var. maximus (guinea grass). Figure 2 shows treatments $\mathrm{B}$ and $\mathrm{E}$ produced more tillering, and thus, biomass.

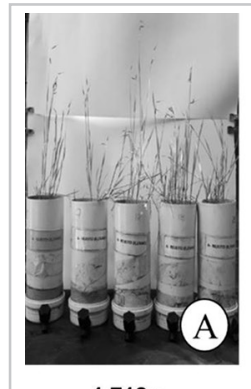

$1.712 \mathrm{~g}$

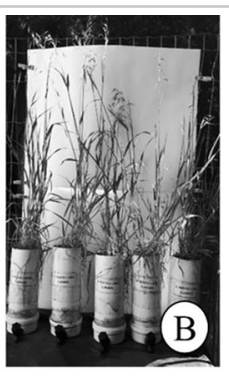

$9.132 \mathrm{~g}$

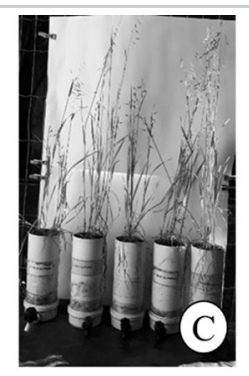

$3.350 \mathrm{~g}$

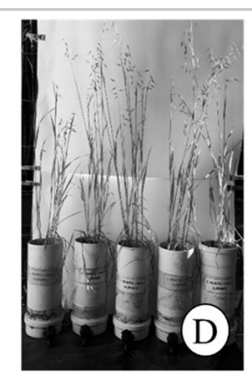

$3.938 \mathrm{~g}$

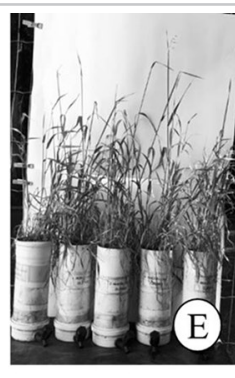

$10.032 \mathrm{~g}$

Figure 2 - Black oats production by treatment $(n=5)$.

Since the capacity of a given soil to promote plant growth is a characteristic to be addressed as to whether it could be used for environmental restoration purposes, it is interesting to point out

\section{Conclusion}

The application rate of sewage sludge (SS) to basalt waste rock (BWR) aiming at 1.8 and $3.2 \%$ soil organic matter was found to be statistically similar with regards to Avena strigosa (black oats) total dry matter production. And when combined, these two treatments produced 2.4, 2.9 and 5.6 times more dry matter than that produced in soil from the same region, soil mixed with BWR, and only BWR, respectively. that treatments B and E produced more dry matter than the natural cover soil. This means that the combination of basalt waste rock with sewage sludge can be more advantageous than the use of borrow soils. It is important to address that the use of sewage sludge in soils must be in accordance with legal standards and economic studies need to be evaluated.
The soil produced by the combination of BWR and SS had a chemical content and physical conditions in accordance to Avena strigosa needs and environmental compliance at both sewage sludge application rates. Drying the sewage sludge at 60 ${ }^{\circ} \mathrm{C}$ was not enough to eliminate Salmonella meaning that further pathogen elimination will be necessary.

These findings open the possibility of using SS as a substitute for borrow soils. The mixture of BWR with SS can be an alternative for reclaiming mine sites impacted by basalt extraction by promoting plant cover and reducing environmental impacts. The use of mine waste and sewage sludge contributes to reducing the need of an area for their disposal, not to mention the extraction of borrow soils for mine restoration. 


\section{Acknowledgement}

The authors would like to thank the Serviços de Água e Esgoto de Novo Hamburgo (COMUSA) for providing the sewage sludge samples that were used in this study.
Also, we would like to thank the Laboratório de Tecnologia Mineral e Ambiental (LTM), the Programa de Pós Graduação em Minas, Metalúrgica e Materiais (PPGE3M), and the Universidade Fedral do Rio Grande do Sul (UFRGS) for their technical and structural support. All help was fundamental for accomplishing this study.

\section{References}

ALMENDRO-CANDEL, M. B.; NAVARRO-PEDREÑO, J.; JORDÁN, M. M.; GÓMEZ, I.; MELÉNDEZ-PASTOR, I. Use of municipal solid waste compost to reclaim limestone quarries mine spoils as soil amendments: Effects on Cd and Ni. Journal of Geochemical Exploration, v. 144, n. 2, p. 363-366, 2014.

ARTICO, L. L.; KOMMLING, G.; MIGITA N. A.; MENEZES A. P. S. Toxicological effects of surface water exposed to coal contamination on the test system Allium cepa. Water, Air, \& Soil Pollution, v. 229, n. 8, p. 248, 2018.

ARTICO, M. Recuperação de áreas degradadas através do uso integrado de lodo de esgoto e rejeito de mineração de basalto como substituto de solo de cobertura. 2018. $121 \mathrm{f}$. Dissertação (Mestrado em Engenharia) - Escola de Engenharia, Universidade Federal do Rio Grande do Sul, Porto Alegre, 2018.

ASSOCIAÇÃO BRASILEIRA DE NORMAS TÉCNICAS. ABNT NBR 10007: Amostragem de resíduos sólidos. Rio de Janeiro: ABNT, 2004. 21 p.

BISSANI, C. A.; GIANELLO, C.; TEDESCO, M. J.; CAMARGO, F. A. O. (ed.). Fertilidade dos solos e manejo da adubação das culturas. Porto Alegre: Gênesis, 2004. 328 p.

BITTENCOURT, S.; SERRA, B. M.; AISSE, M. M. Regulamentação brasileira quanto à frequência de monitoramento de lodo de esgoto para uso agrícola: estudo de caso do estado do Paraná. Revista DAE, v. 65, n. 206, p. 21-31, 2017.

BRASIL. Ministério do Meio Ambiente. Conselho Nacional do Meio Ambiente. Resolução CONAMA n. 375/2006. Define critérios e procedimentos, para o uso agrícola de lodos de esgoto gerados em estações de tratamento de esgoto sanitário e seus produtos derivados. Diário Oficial da União, seção 1, Brasília, DF, n. 167, p. 141-146. 30 ago. 2006.Available at: http://www.mma.gov.br/port/conama/res/res06/res37506.pdf. Accessed: 25 jan 2019.

BRONICK, C. J.; LAL, R. Soil structure and management: a review. Geoderma, v. 124, n. 1, p. 3-22, 2005.

CURI, A. Lavra de minas. São Paulo: Oficina de Textos, 2017. 462 p.

FAGERIA, N. K.; STONE, L. F. Qualidade do solo e meio ambiente. Santo Antônio de Goiás: Embrapa Arroz e Feijão, 2006, 11 p.

FIRPO, B. A.; AMARAL FILHO, J. R.; SCHNEIDER, I. A. H. A brief procedure to fabricate soils from coal mine wastes based on mineral processing, agricultural, and environmental concepts. Minerals Engineering, v. 76, n. 1, p. 81-86, 2015.

FIRPO, B. A. Produção de solo a partir de rejeito de carvão mineral. 2015. 172 f. Tese (Doutorado em Engenharia) Escola de Engenharia, Universidade Federal do Rio Grande do Sul, Porto Alegre, 2015.

HALOFSKY, J. E.; MCCORMICK, L. H. Effects of unseeded areas on species richness of coal mines reclaimed with municipal biosolids. Restoration Ecology, v. 13, n. 4, p.630-638, 2005.

KABATA-PENDIAS, A.; PENDIAS, H. Trace elements in soils and plants. 3th ed. Florida: CRC, 200. 12 p.

MELO, F. A. F.; BRASIL-SOBRINHO, M. O. C.; ARZOLLA, S.; SILVEIRA, R. I.; COBRA-NETTO, A.; KIEHL, J. C. Fertilidade de solos. São Paulo: Nobel, 1983. 400 p.

MELO, W. J.; MARQUES, M. O.; MELO, V. P. O uso agrícola do biossólido e as propriedades do solo. In: TSUTIYA, M. T.; COMPARINI, J. B.; ALEM SOBRINHO, P.; HESPANHOL, I.; CARVALHO, P. C. T.; MELFI, A. J.; MELO, W. J.; MARQUES, M. O. (ed.). Biossólidos na agricultura. 2. ed. São Paulo: ABES/SP, 2002. p. 289-363.

SOCIEDADE BRASILEIRA DE CIÊNCIA DO SOLO. Manual de adubação e de calagem para os estados do Rio Grande do Sul e de Santa Catarina. 10. ed. Porto Alegre: Comissão de Química e Fertilidade do Solo, 2004. 87 p.

TAMANINI, C. R. Recuperação de áreas degradadas com a utilização de biossólido e gramínea forrageira. 2004. 196 f. Dissertação (Mestrado em Agronomia) - Setor de Ciências Agrárias, Universidade Federal do Paraná, Curitiba, 2004.

TAMANINI, C. R.; MOTTA, A. C. V.; ANDREOLI, C. V.; DOETZER, B. H. Land reclamation recovery with the sewage sludge use. Brazilian Archives of Biology and Technology, v. 51, n. 4, p. 643-55, 2008.

TEDESCO, M. J.; GIANELLO, C.; BISSANI, C. A.; BOHNEN, H.; VOLKWEISS, S. J. Análise de solo, plantas e outros materiais. 2. ed. Porto Alegre: Departamento de Solos da UFGRS, 1995. 174 p.

TEIXEIRA, P. C.; DONAGEMMA, G. K.; FONTANA, A.; TEIXEIRA, W. G. Manual de métodos de análise de solo. 3. ed. Brasília: Embrapa, 2017. 21 p.

TIAN, G.; CHIU, C.; FRANZLUEBBERS, A. J.; OLADEJI, O. O.; GRANATO, T. C.; COX, A. E. Biosolids amendment dramatically increases sequestration of crop residue-carbon in agricultural soils in western Illinois. Applied Soil Ecology, v. 85, n. 1, p. 86-93, 2015.

US ENVIRONMENTAL PROTECTION AGENCY. EPA Method 3050B: acid digestion of sediments, sludges and 
soils. Washington: EPA, 1996.

UZAROWICZ, L.; SKIBA, S. Technogenic soils developed on mine spoils containing iron sulphides: Mineral transformations as an indicator of pedogenesis. Geoderma, v. 163, n. 1-2, p. 95-108, 2011.

VON SPERLING, M.; GONÇALVES, R. F. Lodo de esgotos: características e produção. In: ANDREOLI, C. V.; VON SPERLING, M.; FERNANDES, F. (org.). Lodo de esgotos: tratamento e disposição final. Belo Horizonte: Departamento de Engenharia Sanitária e Ambiental, UFMG, 2001. cap. 2, p. 17-67. (Princípios do tratamento biológico de águas residuárias, v. 6).

WATERHOUSE, B. R.; BOYERA, S.; ADAIRA, K. L.; WRATTEN, S. D. Using municipal biosolids in ecological restoration: what is good for plants and soil may not be good for endemic earthworms. Ecological Engineering, v. 70, n. 1, p. 414-421, 2014.

WEILER, J.; FIRPO, B. A.; SCHNEIDER, I. A. H. Coal waste derived soil-like substrate: an opportunity for coal waste in a sustainable mineral scenario. Journal of Cleaner Production, v. 174, n. 1, p. 739-745, 2018.

WIJESEKARA, H.; BOLAN, N. S.; VITHANAGE, M.; XU Y.; MANDAL S.; BROWN, S. L.; HETTIARACHCHI, G. M.; PIERZYNSKI, G. M.; HUANG, L.; OK, Y. S.; KIRKHAM, M. B.; SAINT, C.; SURAPANENI, A. Utilization of biowaste for mine spoil rehabilitation. In: SPARKS, D. L. (ed.). Advances in agronomy. Elsevier, 2016. v. 138, Chapter 2, p. 97-173.

ZORNOZA, R.; ACOSTA, J. A.; FAZ, A.; BÅÅTH, E. Microbial growth and community structure in acid mine soils after addition of different amendments for soil reclamation. Geoderma, v. 272, n. 1, p. 64-72, 2016.

Received: 28 August 2019 - Accepted: 7 October 2019. 